\title{
Absorption properties and size distribution of aerosol particles during the fall season at an urban site of Gwangju, Korea
}

\author{
Seungshik Park ${ }^{\dagger}$, Geun-Hye Yu \\ Department of Environment and Energy Engineering, Chonnam National University, Gwangju 61186, Republic of Korea
}

\begin{abstract}
To investigate the influence of pollution events on the chemical composition and formation processes of aerosol particles, 24-h integrated size-segregated particulate matter (PM) was collected during the fall season at an urban site of Gwangju, Korea and was used to determine the concentrations of mass, water-soluble organic carbon (WSOC) and ionic species. Furthermore, black carbon (BC) concentrations were observed with an aethalometer. The entire sampling period was classified into four periods, i.e., typical, pollution event I, pollution event II, and an Asian dust event. Stable meteorological conditions (e.g., low wind speed, high surface pressure, and high relative humidity) observed during the two pollution events led to accumulation of aerosol particles and increased formation of secondary organic and inorganic aerosol species, thus causing $\mathrm{PM}_{2.5}$ increase. Furthermore, these stable conditions resulted in the predominant condensation or droplet mode size distributions of $\mathrm{PM}^{2}$ WSOC, $\mathrm{NO}_{3}{ }^{-}$, and $\mathrm{SO}_{4}{ }^{2-}$. However, difference in the accumulation mode size distributions of secondary water-soluble species between pollution events I and II could be attributed to the difference in transport pathways of air masses from high-pollution regions and the formation processes for the secondary chemical species. The average absorption Ångström exponent $\left(\mathrm{AAE}_{370-950}\right)$ for $370-950 \mathrm{~nm}$ wavelengths $>1.0$ indicates that the $\mathrm{BC}$ particles from traffic emissions were likely mixed with light absorbing brown carbon $(\mathrm{BrC})$ from biomass burning (BB) emissions. It was found that light absorption by $\mathrm{BrC}$ in the near UV range was affected by both secondary organic aerosol and BB emissions. Overall, the pollution events observed during fall at the study site can be due to the synergy of unfavorable meteorological conditions, enhanced secondary formation, local emissions, and long-range transportation of air masses from upwind polluted areas.
\end{abstract}

Keywords: Asian dust, Brown carbon light absorption, Pollution events, Size distributions, Stable weather conditions

\section{Introduction}

In recent years, the Korean peninsula has suffered from severe air pollution every fall due to stable weather conditions and regional transport of natural and anthropogenic sources from China [1-3]. Stable air conditions such as low wind speed, high surface pressure, and low boundary layer lead to the formation of a low-hanging layer and the poor dispersion of air pollutants. Ambient fine particles $\left(\mathrm{PM}_{2.5}\right)$ consist of primary particles from incomplete combustion of fossil and biomass fuels, and secondary particles formed through homogeneous and heterogeneous oxidation processes of $\mathrm{SO}_{2}, \mathrm{NO}_{2}, \mathrm{NH}_{3}$, and volatile organic compounds (VOCs) from anthropogenic and natural emission sources [4-6]. Haze phenomena, mainly caused by $\mathrm{PM}_{2.5}$, have attracted much attention due to their adverse effect on air quality, public health, and visibility [7-11]. These studies of haze aimed to investigate source identification, chemical characterization, and formation processes of $\mathrm{PM}_{2.5}$ during haze pollution $[5,6$, 12-15].

Generally, it was found that the secondary formation of aerosol components in the atmosphere contributes significantly to the increase in $\mathrm{PM}_{2.5}$ concentration [10, 16, 17]. On a seasonal basis, photochemical reactions during summer are important factors accelerating the formation of secondary $\mathrm{SO}_{4}{ }^{2-}$ particles, which are responsible for summer haze formation [10, 18-21]. Meanwhile, air stagnation and high relative humidity $(\mathrm{RH})$ during winter contribute to the accumulation of aerosol particles from anthropogenic sources and enhanced secondary aerosol formation, giving rise to winter haze formation $[6,8,10,13,22,23]$. Moreover, regional transport could play an important role in the $\mathrm{PM}_{2.5}$ increase during a winter haze event [8-10, 16, 24, 25]. As mentioned above, chemical characteristics of $\mathrm{PM}_{2.5}$ during haze pollution depend on emissions
This is an Open Access article distributed under the terms of the Creative Commons Attribution Non-Commercial License (http://creativecommons.org/licenses/by-nc/3.0/) which permits unrestricted non-commercial use, distribution, and reproduction in any medium, provided the original work is properly cited.

Copyright (C) 2019 Korean Society of Environmental Engineers
Received May 4, 2018 Accepted July 12, 2018

${ }^{\dagger}$ Corresponding author

Email: park8162@chonnam.ac.kr

Fax: +82-62-530-1859

ORCID: 0000-0002-7397-9534 
and transport of air pollutants, formation of secondary aerosols, and meteorological conditions. Thus, understanding the characteristics and mechanisms of $\mathrm{PM}_{2.5}$ pollution occurred at a receptor site is very crucial to establish effective control of the pollution level that depends on the seasonal variation of $\mathrm{PM}_{2.5}$ formation at the site and the surrounding areas.

Atmospheric aerosol particles affect climate radiative forcing of the Earth by directly scattering and absorbing solar radiation [26]. There are two types of carbonaceous aerosols interacting with the radiation. One is the organic carbon (OC) and the other elemental carbon (EC) or black carbon (BC) [19, 20, 27, 28]. $\mathrm{BC}$, which comes from incomplete combustion of fossil and biomass fuels, absorbs light across all ranges from ultraviolet (UV) to infrared (IR) with a weak spectral dependence [29, 30]. While OC has typically been known as light-scattering substances, but a certain type of OC, which is referred to as brown carbon $(\mathrm{BrC})$, absorbs strongly solar radiation in the near UV wavelength range with strong spectral dependence [30,31]. The previous studies have found that $\mathrm{BrC}$ is typically emitted from primary sources such as biomass burning, coal combustion, and vehicles, and produced through the formation of secondary organic aerosol [27, 31-36].

The size distribution of aerosol particles could provide important clues to trace emission sources of ambient particles and the formation pathways of secondary components [37]. Size distributions of water-soluble organic carbon (WSOC) and inorganic components $\left(\mathrm{NO}_{3}{ }^{-}\right.$and $\left.\mathrm{SO}_{4}{ }^{2-}\right)$ under typical ambient conditions at an urban site showed dominant droplet modes peaking at $0.55 \mu \mathrm{m}[2,38$, 39]. Meanwhile particle size distributions at the urban site during the haze event with air stagnation, high $\mathrm{RH}$, and regional transportation, in the fall season, exhibited dominant droplet modes at a particle size of $1.0 \mu \mathrm{m}$ [3]. Yu et al. [2] also conducted a source apportionment of size-resolved WSOC for one year at an urban site. In their study, condensation mode WSOC was found to be strongly associated with secondary organic aerosols and biomass burning (BB) emissions, while heterogeneous reactions and long-range transports were found to be important contributors to the droplet mode WSOC formation. Results from previous studies have indicated that the size distributions of major chemical components in ambient aerosol particles depend on season, location, concentration of precursor gases, meteorological conditions, and long-range transport [2, 3, 38-42]. Therefore, to investigate the cause of haze formation during fall, size distributions of water-soluble chemical species in ambient aerosol particles need to be further explored.

In this study, 24-h size-segregated aerosol particles were collected during the fall season of 2017, at the urban site of Gwangju in Korea, to investigate the difference in characteristics of size-resolved water-soluble chemical species between non-pollution, pollution, and Asian dust (AD) periods. Sources and formation processes of size-resolved WSOC are also discussed. Moreover, the difference in the absorption properties of aerosol particles was examined among non-pollution, pollution, and $\mathrm{AD}$ periods. Further, the size-resolved primary and secondary sources contributing to light absorption by aerosol particles in the near UV range were identified.

\section{Experimental Section}

\subsection{Size-resolved Aerosol Particle Measurements}

Size-segregated particle samples were collected daily between October 19 and November 9, 2017, at the urban site of Gwangju in Korea. The sampling would begin at around 09:00 AM and last approximately 24-h. The sampling site was on the rooftop of a three-story building at Chonnam National University, approximately $150 \mathrm{~m}$ away from a four-lane traffic road. The sampling location is described in detail in our previous publications [2-5, 39]. Collection of size-segregated aerosol samples was conducted using a 10-stage Micro-Orifice Uniform Deposit Impactor (MOUDI, MSP 110; MSP Corp., MN), having cut-off diameters between 0.055 and $18.0 \mu \mathrm{m}(0.055,0.095,0.17,0.32,0.55,1.00,1.8,3.1,6.2$, 9.9 and $18.0 \mu \mathrm{m}$ ) at a flow rate of $30 \mathrm{~L} / \mathrm{min}$. Prebaked and pre-weighed 47-mm Al foil substrates were used to collect aerosol particle samples. Further, a 47-mm Teflon substrate was used as back-up filter. A total of 21 MOUDI sets were collected during the sampling period and used to quantify the concentrations of mass, WSOC, and water-soluble ionic species. Field blanks were also prepared, and their background concentrations were applied to obtain the real concentrations of WSOC and ionic species in ambient aerosol particles.

\subsection{Measurements of Aerosol Light Absorption and Estimation of Brown Carbon Absorption}

$\mathrm{BC}$ concentrations were observed at a time resolution of $1 \mathrm{~min}$ using a dual-spot aethalometer (AE33, Aerosol d.o.o., Slovenia) equipped with a $\mathrm{PM}_{2.5}$ impactor operating at a flow rate of 5.0 $\mathrm{L} / \mathrm{min}$. The aethalometer instrument measures the attenuation of a light beam at seven wavelengths from 370 to $950 \mathrm{~nm}$ by the aerosols loaded on a filter to determine the wavelength-dependent absorption coefficient. Then, the instrument calculates BC concentration by dividing the absorption coefficient by the mass-specific absorption efficiency for each of seven wavelengths. The mass-specific absorption cross-sections used in the BC calculations are $18.47,14.54,13.14,11.58,10.35,7.77$, and $7.19 \mathrm{~m}^{2} / \mathrm{g}$ for 370 , $470,520,590,660,880$, and $950 \mathrm{~nm}$, respectively, which were provided by the manufacturer. The principle on which the BC concentration measurement is based has been documented in detail by Drinovec et al. [43]. BC concentration is typically reported at $880 \mathrm{~nm}$ because organic aerosols as well as BC absorb light at lower wavelengths [30]. Absorption coefficients reported from wavelengths lower than $880 \mathrm{~nm}$ are usually used to identify the absorption of organic aerosols.

BC aerosol strongly absorbs light in the UV to IR wavelength range, but exhibits a weak absorption dependence with wavelength [29]; while a certain type of organic aerosol absorbs strongly radiation in the near UV range but exhibits weaker absorption in the visible wavelengths [30]. The light-absorbing organic carbon components are referred to as BrC. Light absorption coefficients of $\mathrm{BrC}\left(b_{B r C, \lambda}\right)$ at wavelengths less than the $\mathbb{R}$ were derived by subtracting the absorption coefficient by $\mathrm{BC}\left(b_{B C, \lambda}\right)$ from the total light absorption coefficient $\left(b_{a b s, \lambda}\right)$. In this relationship, BC absorption was estimated based on the assumption that the total aerosol light 
absorption at 880 and $950 \mathrm{~nm}$ is due to $\mathrm{BC}$ and the absorption Ångström exponent (AAE) value for $\mathrm{BC}$ is 1.0 [29, 30]. The $b_{B C, \lambda}$ at wavelengths $<880 \mathrm{~nm}$ was calculated by averaging the light absorption at 880 and $950 \mathrm{~nm}$ and extrapolating with an AAE value of 1.0 for $\mathrm{BC}$ [44] (1):

$$
b_{B C, \gamma}=\left(\frac{b_{a b s, 880}+b_{a b s, 950}}{2}\right) \times\left(\frac{\gamma}{\left(\frac{880+950}{2}\right)}\right)^{-A A E_{B C}}
$$

Following the approach of previous studies [29, 30], the wavelength dependence of the light absorption coefficient $\left(b_{a b s, \lambda}\right)$ follows a power law relationship: $b_{a b s, \lambda}=a \lambda^{-A A E}$, where $a$ is the regression constant. Therefore, the aerosol AAE values in the wavelength range of $370-950 \mathrm{~nm}$ and $370-660 \mathrm{~nm}$ were calculated by performing a linear fitting regression of $\ln \left(b_{a b s, \lambda}\right)$ against $\ln (\lambda)$.

\subsection{Determination of Water-soluble Organic and Inorganic Species}

The size-segregated aerosol samples collected on MOUDI were extracted with $30 \mathrm{~mL}$ of ultrapure distilled de-ionized water for 60 min of ultra-sonication at room temperature. Then the water extracts were filtered with a disposable syringe filter $(0.45 \mu \mathrm{m}$ pore size, Millipore) to analyze the WSOC and ionic species $\left(\mathrm{Na}^{+}\right.$, $\mathrm{NH}_{4}{ }^{+}, \mathrm{K}^{+}, \mathrm{Ca}^{2+}, \mathrm{Mg}^{2+}, \mathrm{Cl}^{-}, \mathrm{NO}_{3}{ }^{-}, \mathrm{SO}_{4}{ }^{2-}$, and oxalate) using a total organic carbon analyzer (TOC, Sievers 5310C, USA) and an ion chromatography (IC) system (Metrohm 861), respectively. In the TOC analyzer, the organic compounds soluble in water are oxidized to form carbon dioxide $\left(\mathrm{CO}_{2}\right)$ using UV radiation and a chemical oxidizing agent (ammonium persulfate, $\left(\mathrm{NH}_{4}\right)_{2} \mathrm{~S}_{2} \mathrm{O}_{8}$ ). The $\mathrm{CO}_{2}$ concentration is measured using a sensitive membrane-based conductivity detection technique. The IC system has an anion IC (a Metrohm Metrosep A Supp-5, 4×150 mm, anion column) and a cation IC (a Metrohm Metrosep C4, 4×150 $\mathrm{mm}$, cation column). For the anion analysis, a $3.2 \mathrm{mM}$ sodium carbonate/1.0 mM sodium bicarbonate solution was used as the eluent. The cation eluent was $1.7 \mathrm{mM}$ nitric acid/0.7 $\mathrm{mM}$ dipicolinic acid. Eluant flow rate for the anion and cation was 0.7 and $1.0 \mathrm{~mL} / \mathrm{min}$, respectively. The method detection limit (MDL) of ionic species was calculated as the average blank value plus three times the standard deviation of the field blanks. The MDL for $\mathrm{Na}^{+}, \mathrm{NH}_{4}{ }^{+}, \mathrm{K}^{+}, \mathrm{Ca}^{2+}, \mathrm{Mg}^{2+}, \mathrm{Cl}^{-}, \mathrm{NO}_{3}{ }^{-}, \mathrm{SO}_{4}{ }^{2-}$, and oxalate was $0.07,0.05,0.11,0.07,0.10,0.09,0.10,0.05,0.05 \mu \mathrm{g} / \mathrm{m}^{3}$, respectively. Their sample precision was $2.6,4.1,4.4,1.1,1.3$, $4.2,5.5,5.2$, and $6.7 \%$, respectively. Detail descriptions for analyzing the WSOC and ionic species can be found in our previous publications [27, 35].

\section{Results and Discussion}

\subsection{General Features of $\mathrm{PM}_{10}$ and $\mathrm{PM}_{2.5}$, and Classification of Study Period}

Fig. 1 shows temporal variations of hourly and 24-h averaged $\mathrm{PM}_{10}, \mathrm{PM}_{2.5}$, and $\mathrm{PM}_{2.5} / \mathrm{PM}_{10}$ as well as $\mathrm{O}_{3}, \mathrm{NO}_{2}, \mathrm{CO}$, and $\mathrm{SO}_{2}$. Hourly concentrations of $\mathrm{PM}_{10}, \mathrm{PM}_{2.5}, \mathrm{O}_{3}, \mathrm{NO}_{2}, \mathrm{SO}_{2}$, and $\mathrm{CO}$ were observed at an urban air monitoring station at Duam-dong, which is approximately $2.0 \mathrm{~km}$ from the sampling site. The $\mathrm{PM}_{10}$ and $\mathrm{PM}_{2.5}$ were observed by using two beta attenuation mass monitors (BAM-1020), respectively. The gaseous species $\mathrm{O}_{3}, \mathrm{NO}_{2}, \mathrm{SO}_{2}$, and $\mathrm{CO}$ concentrations were measured by using a pulsed ultraviolet photometric ozone analyzer (Thermo 49i), chemiluminescencebased analyzer (Thermo 42CTL), a pulsed ultraviolet fluorescence $\mathrm{SO}_{2}$ analyzer (Thermo 43i), and a non-dispersive infrared CO analyzer (Thermo 48i), respectively. 24-h averaged $\mathrm{PM}_{10}, \mathrm{PM}_{2.5}$, and $\mathrm{PM}_{2.5} / \mathrm{PM}_{10}$ were in the range of $24-70 \mu \mathrm{g} / \mathrm{m}^{3}, 14-62 \mu \mathrm{g} / \mathrm{m}^{3}$, and 0.36-0.93, respectively. The Korean Meteorological Agency reported that an $\mathrm{AD}$ event during the study period occurred on 8 November, 2017 (http://www.weather.go.kr/weather/asiandus t). Hence, we classified the sampling period for November 8 as the $\mathrm{AD}$ event. During the $\mathrm{AD}$ event, the hourly maximum $\mathrm{PM}_{10}$ and $\mathrm{PM}_{2.5}$ concentrations reached 193 and $76 \mu \mathrm{g} / \mathrm{m}^{3}$ at 14:00 and 11:00 on November 08, respectively. In addition, the $\mathrm{PM}_{2.5} / \mathrm{PM}_{10}$ was observed to be the lowest at 17:00 $\mathrm{h}$ with a value of 0.30 . During that day, the 24-h averaged $\mathrm{PM}_{2.5}$ concentration was $31 \mu \mathrm{g} / \mathrm{m}^{3}$. Based on the 24-h $\mathrm{PM}_{2.5}$ concentration and the $\mathrm{AD}$ event, the entire study period was classified into four periods of which, $\mathrm{PM}_{2.5}$ pollution events were identified as those periods when daily $\mathrm{PM}_{2.5}$ exceeded the 24-h averaged Korean National Ambient Air Quality Standard of $35.0 \mu \mathrm{g} / \mathrm{m}^{3}$. Daily $\mathrm{PM}_{2.5}$ values were calculated based on the measurement interval of MOUDI (09:00-09:00). Using the results of this calculation, a total of seven sampling days (October 25-27 and November 01-04) were identified as $\mathrm{PM}_{2.5}$ pollution days. The 24-h averaged $\mathrm{PM}_{2.5}$ masses on October 25, 26, 27; November 01, 02, 03, and 04 were 46, $55,50,40,54,56$, and $62 \mu \mathrm{g} / \mathrm{m}^{3}$, respectively. Hence, sampling periods for October 25-27, November 01-04, and November 08 were designated as pollution event I, pollution event II, and $\mathrm{AD}$ event. Those periods not falling within these three designated events were classified as typical period. Table 1 summarizes $\mathrm{PM}_{10}$, $\mathrm{PM}_{2.5}$, criteria gases $\left(\mathrm{O}_{3}, \mathrm{NO}_{2}, \mathrm{CO}\right.$, and $\left.\mathrm{SO}_{2}\right)$, aerosol light absorption, and concentrations of water-soluble chemical species from MOUDI measurements for four periods. In addition, meteorological data (wind speed, relative humidity, surface pressure), which were observed at Gwangju regional office of meteorology (http://www.weather.go.kr/weather/observation/aws_table_popup. jsp), are provided in Table 1. Fig. 2 shows temporal profiles of hourly and 24-h averaged meteorological parameters (ambient temperature, relative humidity, wind speed, and sea level pressure).

For typical, pollution event I, pollution event II, and the $\mathrm{AD}$ event, average $\mathrm{PM}_{2.5}$ concentrations were 25.6, 50.1, 53.0, and $30.8 \mu \mathrm{g} / \mathrm{m}^{3}$, respectively. Respective $\mathrm{PM}_{2.5} / \mathrm{PM}_{10}$ ratios were 0.62 , 0.76, 0.86, and 0.54. As shown in Fig. 2 and Table 1, higher $\mathrm{PM}_{2.5}$ and $\mathrm{PM}_{2.5} / \mathrm{PM}_{10}$ during the two pollution events were attributed to low wind speeds $(0.6-0.9 \mathrm{~m} / \mathrm{s})$ and high $\mathrm{RH}(74-76 \%)$. These meteorological conditions could accelerate the accumulation of primary particles from traffic emissions around the site and the production of secondary aerosol particles through VOC, $\mathrm{SO}_{2}, \mathrm{NO}_{2}$, and $\mathrm{NH}_{3}$ oxidation processes, leading to an increase in $\mathrm{PM}_{2.5}$. Results from previous studies have indicated that high RH conditions could lead to enhanced formation of secondary inorganic species through aqueous-phase oxidations of $\mathrm{SO}_{2}$ and $\mathrm{NO}_{2}$ [8-10, $23,45,46]$. Higher concentrations of $\mathrm{CO}$ from combustion emission 

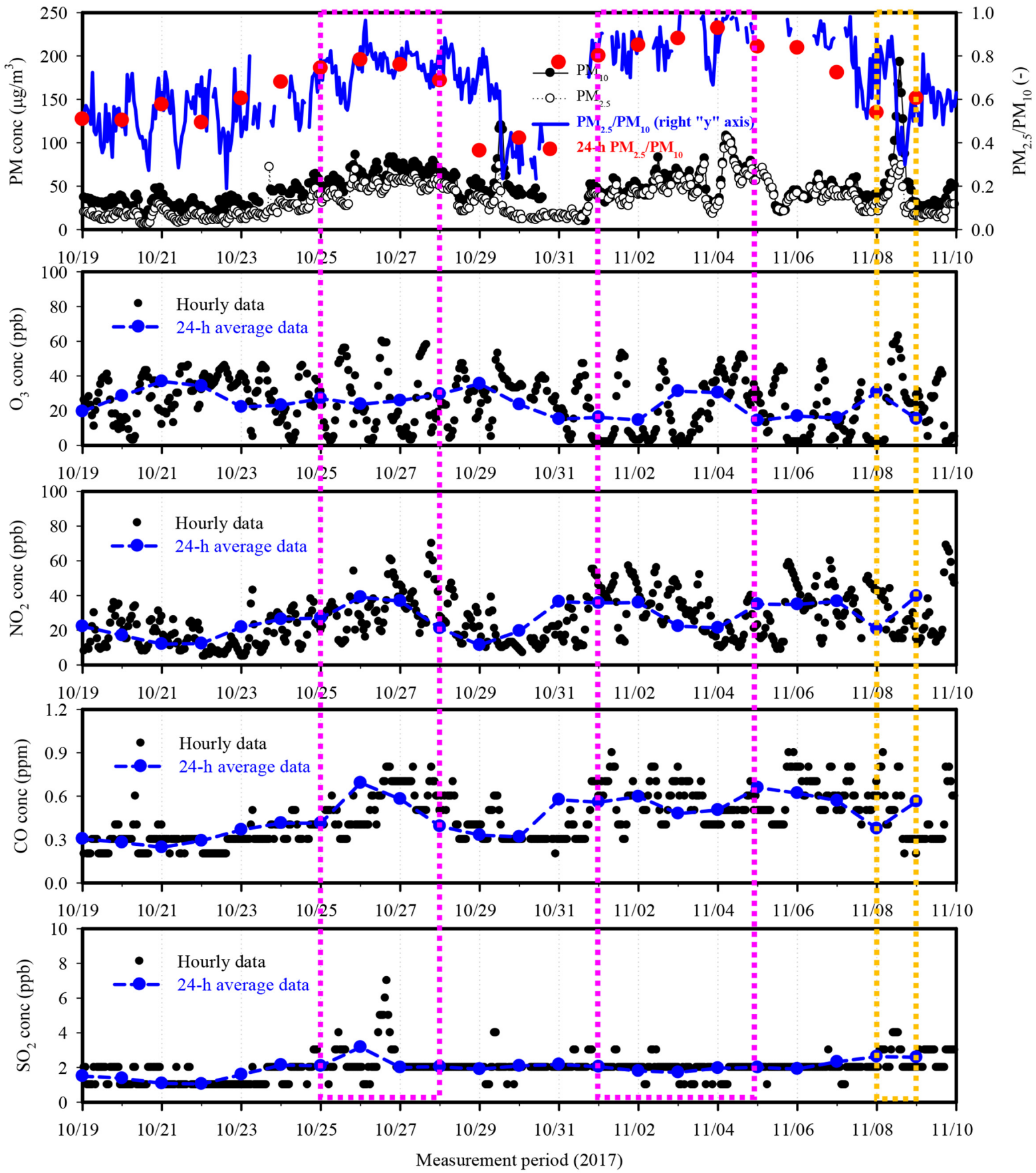

Fig. 1. Temporal profiles of hourly and 24-h average $\mathrm{PM}_{10}, \mathrm{PM}_{2.5}, \mathrm{PM}_{2.5} / \mathrm{PM}_{10}, \mathrm{O}_{3}, \mathrm{NO}_{2}, \mathrm{CO}$, and $\mathrm{SO}_{2}$ over the study period.

sources were observed during the two pollution events than during the other two periods, suggesting greater contributions from combustion sources to aerosol particles during pollution events I and II. As shown in Fig. 1, the average CO concentrations during typical, pollution event I, pollution event II, and $\mathrm{AD}$ event were 0.42 (0.20-0.90), 0.56 (0.30-0.80), 0.53 (0.30-0.80), and 0.38 (0.20-0.80) ppm, respectively. As described above and also in Table 1, there was little difference in meteorological variables such as wind speed and $\mathrm{RH}$, and concentrations of $\mathrm{O}_{3}, \mathrm{NO}_{2}$, and $\mathrm{CO}$ between pollution events I and II. However, the higher $\mathrm{PM}_{2.5} / \mathrm{PM}_{10}$ observed during pollution event II (0.86) could be attributed to a greater influx of long-range transported fine aerosols from polluted regions in China, as suggested by the analysis of transport pathways of air masses and MODIS images below.

To investigate the difference in $\mathrm{PM}_{2.5} / \mathrm{PM}_{10}$, light absorption by aerosol particles, and its chemical composition between the 


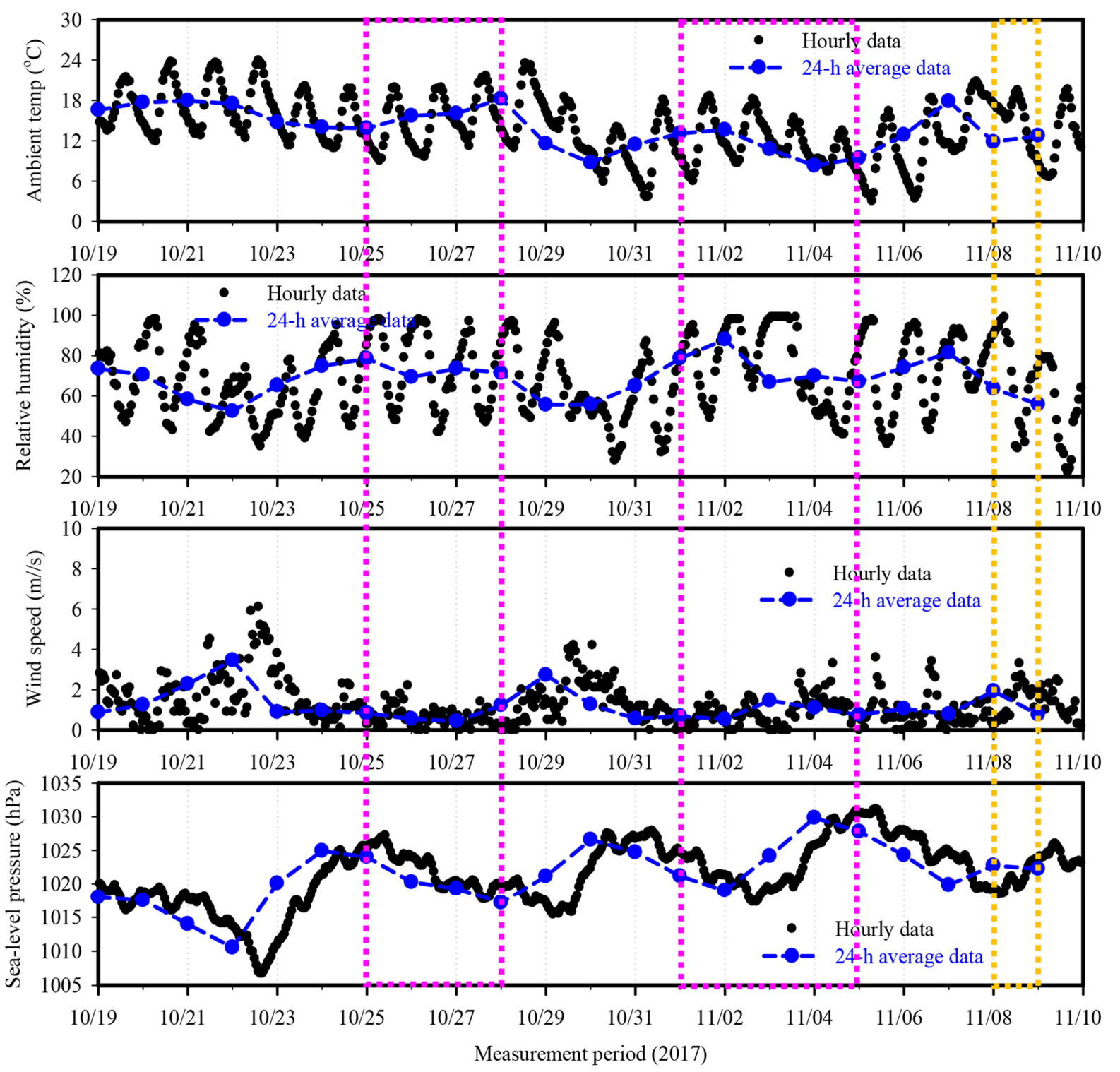

Fig. 2. Temporal profiles of hourly and 24-h average temperature, relative humidity, wind speed, and sea level pressure.

pollution events I and II, air mass backward trajectories were computed. The transport pathways of air masses were calculated using the Hybrid Single-Particle Lagrangian Integrated Trajectories (HYSPLIT 5.0) model [47]. Three-day backward trajectories with model vertical velocity were calculated for 0900 UTC on each day at three altitudes (500, 1,000, and 1,500 m) above ground level (AGL). Fig. 3 shows transport pathways of air masses arriving at the site during pollution events I (Oct 25, 26, and 27) and II (Nov. 01, 02, 03, 04), and MODIS images of days before these two pollution events began. During pollution event I, haze occurred over the mid-eastern Chinese regions (MODIS images, http:// nmsc.kma.go.kr/html/homepage/ko/satellite/searchSatelliteImageN. do?data_type $=1012$ ), but most of the air masses originated from northern China and north Korea, indicating that the air masses were likely dominated by local pollution. Similarly, during pollution event II, haze layers occurred over the mid-eastern regions of China (MODIS images). A small amount of the haze passed over the western sea of the Korean peninsula and reached the study site, indicating that the air masses arriving at the site were influenced by a mixture of the haze transported from mid-eastern China as well as the local pollution. In summary, local combustion emissions (e.g., traffic emissions) and enhanced formation of secondary ionic species under stable air conditions (see Table 1) were important contributors to high $\mathrm{PM}_{2.5}$ during pollution event I, while the long range transportation of polluted aerosols from mid-eastern Chinese regions, local emissions, and further processing of air pollutants under stable air conditions could be possible factors contributing to high $\mathrm{PM}_{2.5}$ during pollution event II. 

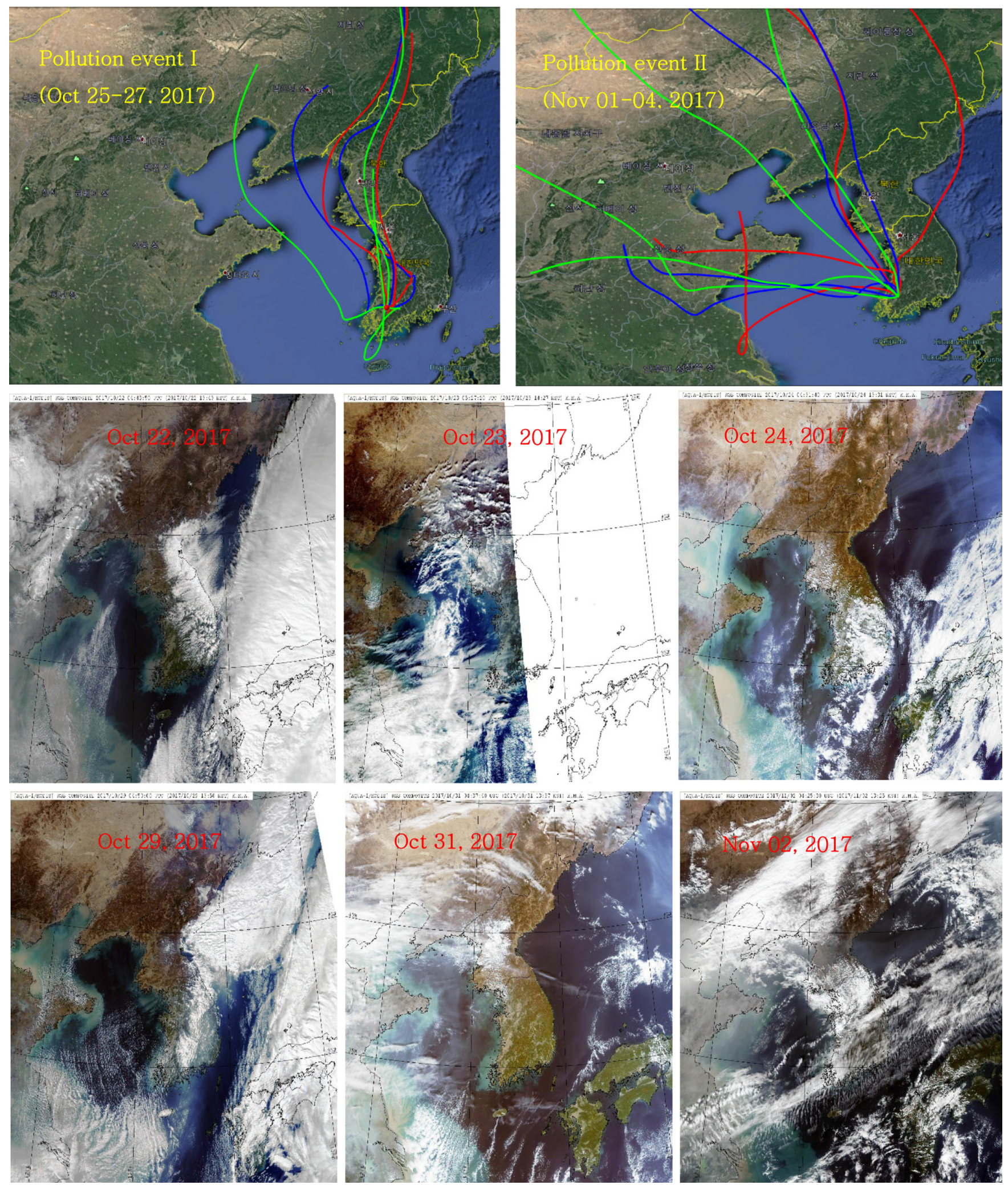

Fig. 3. Air mass transport pathways and MODIS images around the Korean peninsula prior to the pollution events I and II. Red, blue, and green lines on backward trajectories (upper) indicate heights of 500, 1,000, and 1,500 m AGL. 
Table 1. A Summary of Measurement Data for Four Different Periods

\begin{tabular}{|c|c|c|c|c|c|}
\hline Item & Unit & Typical & Event I & Event II & AD event \\
\hline $\mathrm{PM}_{10}$ & $\mu \mathrm{g} / \mathrm{m}^{3}$ & $40.1 \pm 14.7$ & $65.7 \pm 9.1$ & $58.1 \pm 17.9$ & $63.8 \pm 10.0$ \\
\hline $\mathrm{PM}_{2.5}$ & $\mu \mathrm{g} / \mathrm{m}^{3}$ & $25.6 \pm 12.1$ & $50.1 \pm 8.5$ & $53.0 \pm 19.4$ & $30.8 \pm 10.0$ \\
\hline $\mathrm{PM}_{2.5} / \mathrm{PM}_{10}$ & - & $0.62 \pm 0.19$ & $0.76 \pm 0.08$ & $0.86 \pm 0.14$ & $0.54 \pm 0.12$ \\
\hline $\mathrm{O}_{3}$ & $\mathrm{ppb}$ & $24 \pm 15$ & $25 \pm 18$ & $23 \pm 17$ & $31 \pm 15$ \\
\hline $\mathrm{NO}_{2}$ & $\mathrm{ppb}$ & $25 \pm 14$ & $34 \pm 13$ & $29 \pm 13$ & $21 \pm 10$ \\
\hline $\mathrm{CO}$ & ppm & $0.42 \pm 0.18$ & $0.56 \pm 0.14$ & $0.53 \pm 0.12$ & $0.38 \pm 0.13$ \\
\hline $\mathrm{SO}_{2}$ & $\mathrm{ppb}$ & $1.8 \pm 0.6$ & $2.4 \pm 1.5$ & $1.9 \pm 0.5$ & $2.6 \pm 0.4$ \\
\hline Temperature & ${ }^{\circ} \mathrm{C}$ & $14.0 \pm 3.2$ & $15.2 \pm 1.2$ & $11.4 \pm 2.4$ & $11.8 \pm 4.7$ \\
\hline Wind speed & $\mathrm{m} / \mathrm{s}$ & $1.3 \pm 0.9$ & $0.6 \pm 0.2$ & $0.9 \pm 0.4$ & $1.9 \pm 0.5$ \\
\hline Relative humidity & $\%$ & $66 \pm 9$ & $74 \pm 5$ & $76 \pm 10$ & $64 \pm 16$ \\
\hline Surface pressure & $\mathrm{hPa}$ & $1,021 \pm 5$ & $1,021 \pm 2$ & $1,024 \pm 5$ & $1,023 \pm 2$ \\
\hline \multicolumn{6}{|c|}{ Aethalometer measurements } \\
\hline $\mathrm{BC}_{370}$ & $\mu \mathrm{g} / \mathrm{m}^{3}$ & $2.7 \pm 1.9$ & $4.8 \pm 1.6$ & $4.2 \pm 1.7$ & $2.0 \pm 2.5$ \\
\hline $\mathrm{BC}_{880}$ & $\mu \mathrm{g} / \mathrm{m}^{3}$ & $2.0 \pm 1.4$ & $3.5 \pm 1.2$ & $2.7 \pm 1.4$ & $1.4 \pm 1.9$ \\
\hline $\mathrm{b}_{\mathrm{abs}, 370}$ & 1/Mm & $50 \pm 35$ & $88 \pm 30$ & $77 \pm 12$ & $37 \pm 47$ \\
\hline $\mathrm{b}_{\mathrm{abs}, 880}$ & 1/Mm & $15 \pm 11$ & $27 \pm 9$ & $20 \pm 7$ & $11 \pm 15$ \\
\hline BC $b_{a b s, 370}$ & 1/Mm & $37 \pm 26$ & $65 \pm 22$ & $47 \pm 16$ & $26 \pm 36$ \\
\hline $\mathrm{BrC} \mathrm{b}_{\mathrm{abs}, 370}$ & 1/Mm & $13 \pm 10$ & $24 \pm 11$ & $30 \pm 4$ & $11 \pm 13$ \\
\hline $\mathrm{BrC}_{370}$ & $\%$ & 27 & 26 & 40 & 33 \\
\hline $\mathrm{AAE}_{370-950}$ & - & 1.3 & 1.3 & 1.5 & 1.4 \\
\hline $\mathrm{BrC} \mathrm{AAE}_{370-660}$ & - & 4.5 & 4.3 & 4.6 & 4.2 \\
\hline \multicolumn{6}{|c|}{ MOUDI measurements } \\
\hline $\mathrm{PM}_{1.8}$ WSOC & $\mu \mathrm{gC} / \mathrm{m}^{3}$ & $1.7 \pm 0.8$ & $4.2 \pm 0.7$ & $4.1 \pm 1.6$ & 1.5 \\
\hline $\mathrm{PM}_{1.8} \mathrm{NO}_{3}^{-}$ & $\mu \mathrm{g} / \mathrm{m}^{3}$ & $2.4 \pm 1.7$ & $8.8 \pm 1.0$ & $6.8 \pm 3.1$ & 4.5 \\
\hline $\mathrm{PM}_{1.8} \mathrm{SO}_{4}^{2-}$ & $\mu \mathrm{g} / \mathrm{m}^{3}$ & $2.0 \pm 1.1$ & $4.9 \pm 0.6$ & $5.6 \pm 1.2$ & 4.9 \\
\hline $\mathrm{PM}_{1.8}$ oxalate & $\mu \mathrm{g} / \mathrm{m}^{3}$ & $0.2 \pm 0.1$ & $0.5 \pm 0.2$ & $0.7 \pm 0.2$ & 0.4 \\
\hline $\mathrm{PM}_{1.8} \mathrm{NH}_{4}^{+}$ & $\mu \mathrm{g} / \mathrm{m}^{3}$ & $1.4 \pm 0.7$ & $4.1 \pm 0.6$ & $3.1 \pm 0.2$ & 2.0 \\
\hline $\mathrm{PM}_{1.8} \mathrm{~K}^{+}$ & $\mu \mathrm{g} / \mathrm{m}^{3}$ & $0.5 \pm 0.1$ & $0.7 \pm 0.2$ & $0.7 \pm 0.1$ & 0.6 \\
\hline
\end{tabular}

\subsection{BC Concentration and Light Absorption by BC and Brown Carbon}

Temporal profiles of hourly $\mathrm{BC}_{880}$, aerosol absorption coefficients ( $b_{a b s, 370}$ and $b_{a b s, 880}$ ), estimated absorption coefficients of BC and $\mathrm{BrC}\left(\mathrm{BC} \mathrm{b}_{\mathrm{abs}, 370}\right.$ and $\left.\mathrm{BrC} \mathrm{b}_{\mathrm{abs}, 370}\right)$, and $\mathrm{BrC}$ contribution to total aerosol absorption at $370 \mathrm{~nm}\left(\mathrm{BrC}_{370}\right)$ are shown in Fig. 4. Subscripts 370 and 880 denote wavelengths of $370 \mathrm{~nm}$ and $880 \mathrm{~nm}$, respectively. The 24-h averaged $\mathrm{BC}_{370}$ ranged from 0.8 to $5.6 \mu \mathrm{g} / \mathrm{m}^{3}$, which were higher than the average $\mathrm{BC}_{880}$. In addition, the average $\mathrm{b}_{\mathrm{abs}, 370}$ ranged from 15.0 to $103.7 \mathrm{Mm}^{-1}$, which is approximately 2.9-4.7 times the average $b_{a b s, 880}$ with a range of 5.1-32.3 $\mathrm{Mm}^{-1}$. The large difference in the aerosol absorption coefficients at wavelengths of 370 and $880 \mathrm{~nm}$ suggests the presence of light absorbing organic aerosols, as well as the $\mathrm{BC}$ aerosols at the site. As shown in Table $1, \mathrm{BC}_{370}, \mathrm{BC}_{880}, \mathrm{~b}_{\mathrm{abs}, 370}$, and $\mathrm{b}_{\mathrm{abs}, 880}$ were higher during the two pollution events than during the other two periods, with the highest values during pollution event I. However, $b_{a b s, 370} / b_{a b s, 880}$ was highest during pollution event II at 3.9, suggesting the greatest contribution of light absorbing $\mathrm{BrC}$ to total aerosol absorption during pollution event II, which is discussed in detail in the following section. Over the study period, the contribution of $\mathrm{BC} \mathrm{b}_{\mathrm{abs}, 370}$ to total aerosol absorption at $370 \mathrm{~nm}$ ranged from $26 \mathrm{Mm}^{-1}$ during the $\mathrm{AD}$ event to $65 \mathrm{Mm}^{-1}$ during pollution event I. On the other hand, the contribution of $\mathrm{BrC} \mathrm{b}_{\mathrm{abs}, 370}$ ranged from $11 \mathrm{Mm}^{-1}$ during the $\mathrm{AD}$ event to $30 \mathrm{Mm}^{-1}$ during pollution event II, accounting for $26-40 \%$ of total aerosol absorption at $370 \mathrm{~nm}$. From the $\mathrm{BC}_{880}$, $\mathrm{b}_{\mathrm{abs}, 880}$, and $\mathrm{BC} \mathrm{b}_{\mathrm{abs}, 370}$, it was confirmed that the contribution from local traffic, which emits $\mathrm{BC}$ particles, was dominant during pollution event I, while contribution by $\mathrm{BrC}$ aerosols was dominant during pollution event II. As shown in Table 1, light absorption at 370 and $880 \mathrm{~nm}$ during the $\mathrm{AD}$ event was observed to be lower than that during typical period. The low absorption was due to low concentration of light-absorbing aerosol particles from anthro- 

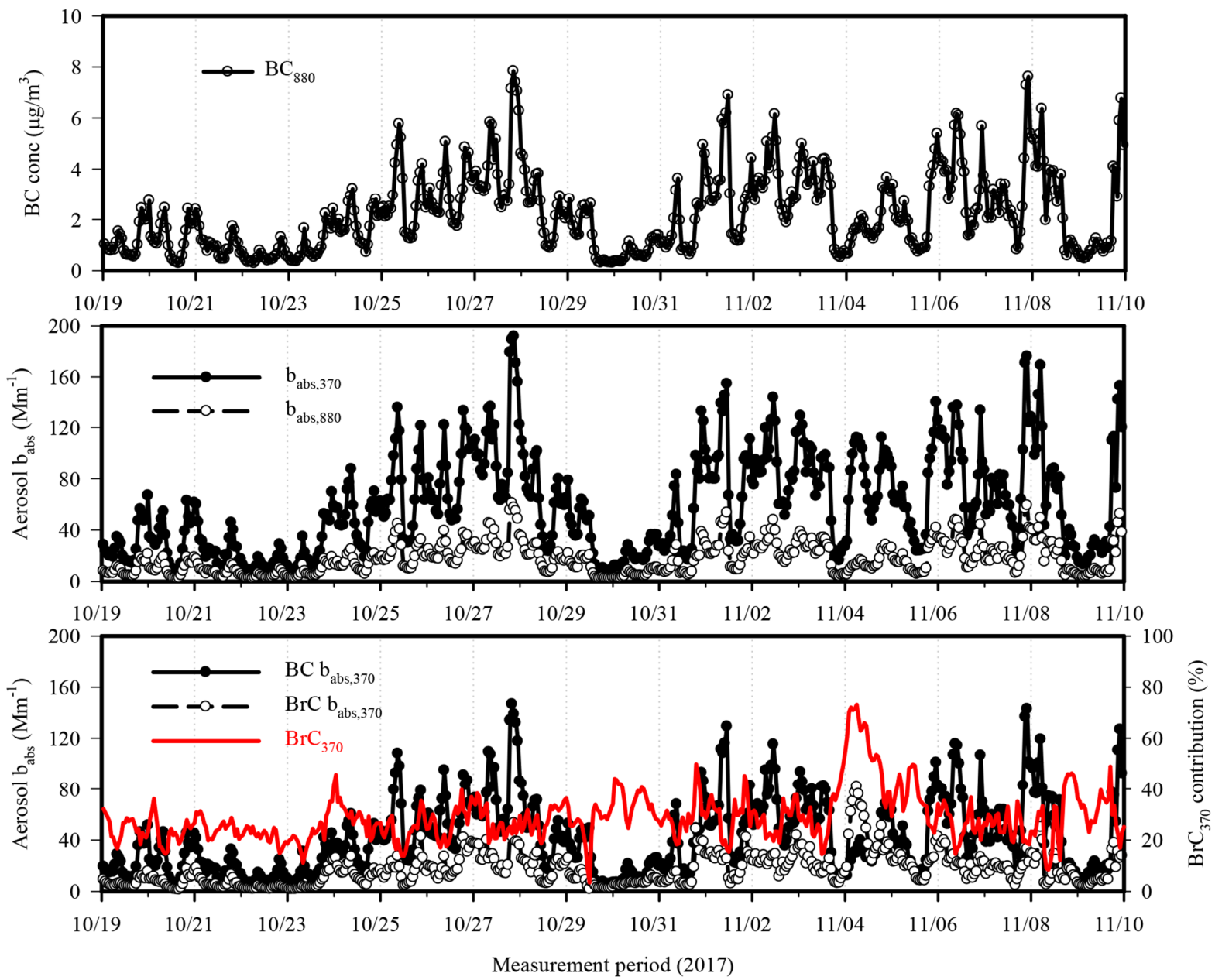

Fig. 4. Temporal profiles of hourly $\mathrm{BC}_{880}, \mathrm{~b}_{\mathrm{abs}, 370}, \mathrm{~b}_{\mathrm{abs}, 880}, \mathrm{BC} \mathrm{b}_{\mathrm{abs}, 380}, \mathrm{BrC} \mathrm{b}_{\mathrm{abs}, 370}$, and $\mathrm{BrC}_{370}$ contribution.

pogenic emission sources and low concentration of mineral dust particles. Generally, the mineral dust particles have an absorption cross-section smaller than that of BC particles by a factor of from 100 to 1,000 . Thus, if the amount of dust particle is 100 to 1,000 times greater than that of $\mathrm{BC}$, a comparable light absorption may be produced [48]. However, the hourly highest concentration of $\mathrm{PM}_{2.5}$ observed during the $\mathrm{AD}$ event was $76 \mu \mathrm{g} / \mathrm{m}^{3}$ at the most. Moreover, the aethalometer instrument measures light absorption by $\mathrm{PM}_{2.5}$. Thus, the contribution of the mineral dust particles to the total aerosol absorption could be low.

The spectral dependence of aerosol and estimated BrC absorption for four sampling periods are shown in Fig. 5. In Fig. 5, the wavelength dependence of aerosol absorption follows a power-law relationship $\left(b_{\mathrm{abs}}=\mathrm{a} \times \lambda^{-\mathrm{AAE}}\right)$, with decrease in the aerosol absorption with wavelength. Average aerosol $\mathrm{AAE}_{370-950}$ values for typical, pollution event I, pollution event II, and the $\mathrm{AD}$ event were $1.3,1.3,1.5$, and 1.4, respectively. $\mathrm{AAE}_{370-950}$ values greater than 1.0 could indicate that the aerosol particles collected at the site was due to biomass burning (BB) emissions and the $\mathrm{BC}$ aerosols from traffic emissions [3, 27, 29, 30]. Moreover, little difference in estimated $\mathrm{BrC} \mathrm{AAE}_{370-660}$ values was observed among the four periods, ranging from 4.2 (AD event) to 4.6 (pollution event II), suggesting that organic aerosols contributed to total aerosol absorption throughout the study period. In general, the AAE values are close to 1.0 for $\mathrm{BC}$ aerosols from motor vehicle emissions, while organic aerosols from $\mathrm{BB}$ emissions have an $\mathrm{AAE}$ of approximately $2.0[29,30,49,50]$. Furthermore, AAE values are larger than 2.0 for dust aerosols [50]. The AAE of 2.27 was obtained from the ACE-Asia program during which collected particles had both urban pollution and desert dust components [51]. Sun et al. [52] suggested that the absorption coefficients can be approximated with an AAE of 6 for the humic-like substances, which are a type of $\mathrm{BrC}$ aerosols, and an AAE of 4.3 for the combustion substances. Their results indicate that mixtures of these organic materials and $\mathrm{BC}$ have AAE values greater than 1 but less than 4-6. Although the AAE can be very high (4-6) for individual organic compounds, these compounds in the atmosphere are usually mixed with strongly absorbing BC particles. Therefore, the average AAE usually lies between 1 (for $\mathrm{BC}$ ) and 4-6 (for $\mathrm{BrC}$ ). Based on previous results, $\mathrm{AAE}$ greater than 1.0 for the four different periods was associated 
with the presence of mixtures of $\mathrm{BC}$ and light absorbing organic aerosols.

As shown in Fig. 6, $\mathrm{PM}_{2.5}$ ranged from 18 to $32 \mu \mathrm{g} / \mathrm{m}^{3}$ between 18:00 on Nov 03 and 01:00 on Nov 04 ("A" period) but thereafter maintained relatively high values $\left(51-105 \mu \mathrm{g} / \mathrm{m}^{3}\right)$ between 02:00 $\mathrm{AM}$ and 12:00 PM on Nov. 04 ("B" period). Enhanced concentrations of $\mathrm{PM}_{2.5}$ were observed early in the morning, and maximum $\mathrm{PM}_{2.5}$ concentration was observed between 05:00-06:00 AM on Nov. 04 To investigate the difference in $\mathrm{PM}_{2.5}$ between the two distinct periods, we examined the meteorological parameters (wind speed and $\mathrm{RH}$ ), concentrations of criteria gases, air mass transport pathways, $\mathrm{BC}$ concentrations, and $\mathrm{AAE}$ values calculated from absorptions by aerosol and $\mathrm{BrC}$. However meteorological parameters such as wind speed and $\mathrm{RH}$ controlling PM concentrations did not significantly differ between the two time intervals. Moreover, no significant difference in $\mathrm{O}_{3}, \mathrm{NO}_{2}, \mathrm{CO}, \mathrm{SO}_{2}$, and transport pathways of air masses was found between the two time intervals. Wind speed and $\mathrm{RH}$ were $0.7-1.9 \mathrm{~m} / \mathrm{s}$ and $52-65 \%$ during "A" period, and 1.1-2.4 m/s and $43-56 \%$ during " $\mathrm{B}$ " period. $\mathrm{BC}_{880}$ and $\mathrm{BC}_{370}$ concentrations were 0.5-0.8 and 0.9-1.7 $\mu \mathrm{g} / \mathrm{m}^{3}$ during " $\mathrm{A}$ " period,
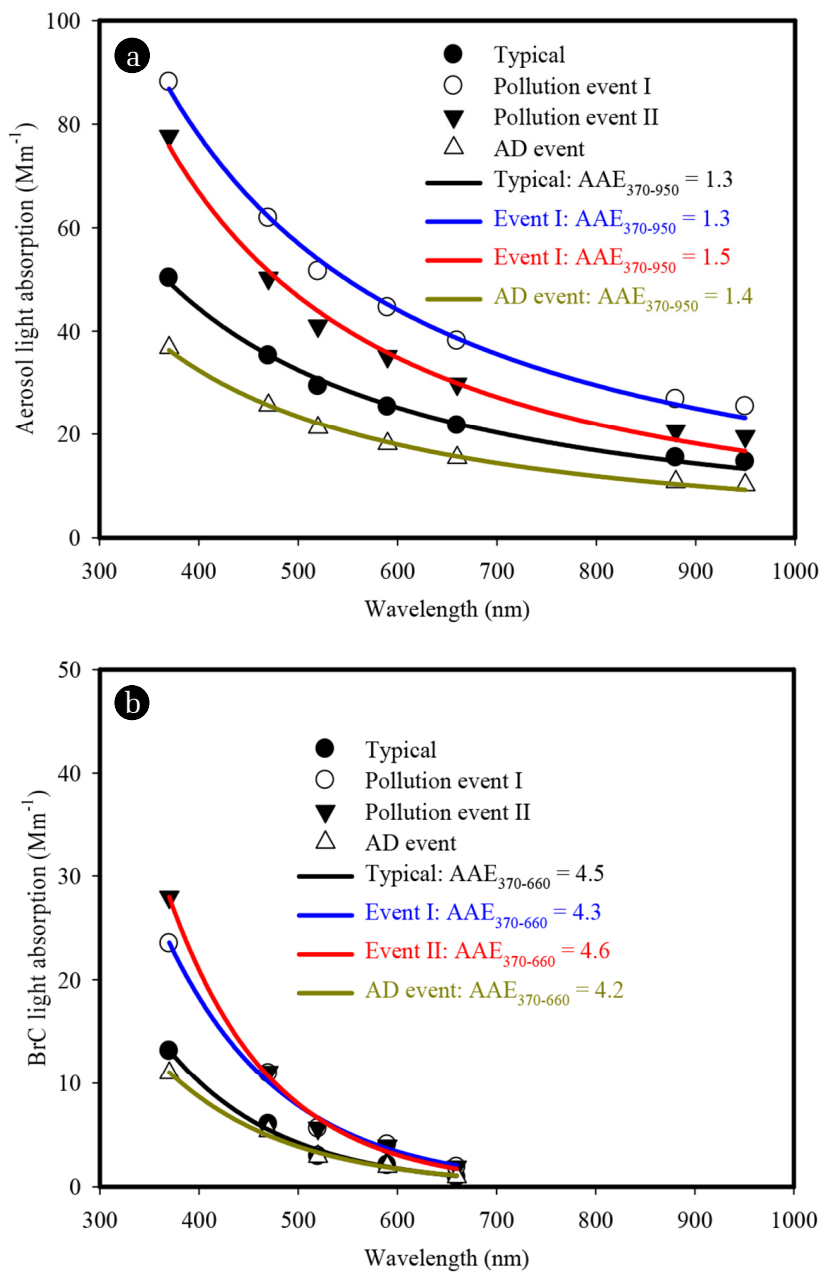

Fig. 5. Spectral dependence of light absorption coefficients by aerosol (a) and $\mathrm{BrC}$ (b) for four different periods.

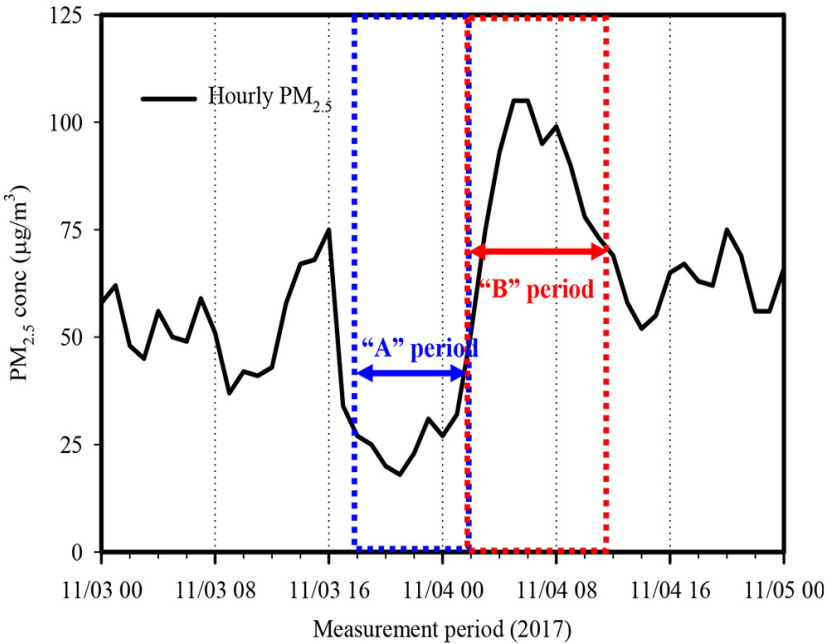

Fig. 6. Hourly variation of $\mathrm{PM}_{2.5}$ for two distinct periods during pollution event II.
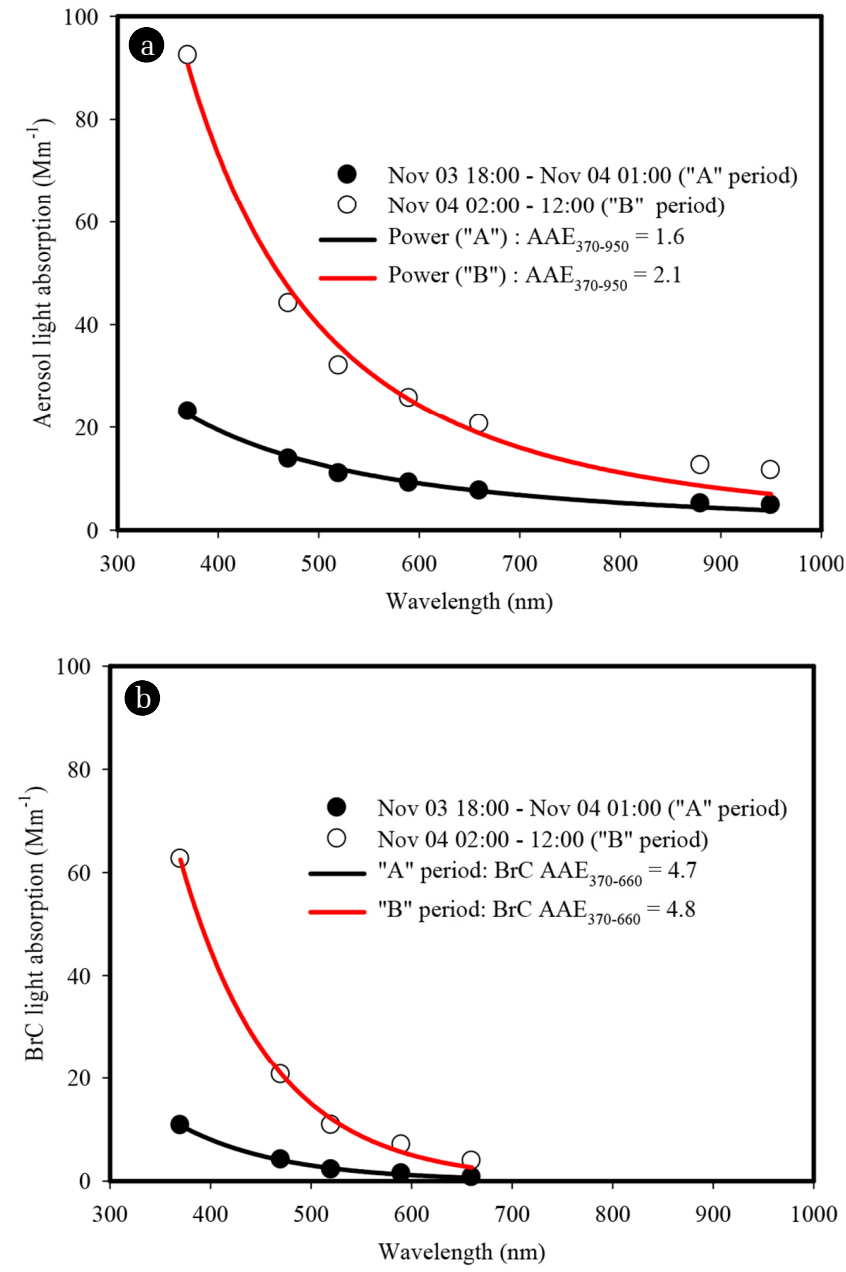

Fig. 7. Spectral dependence of light absorption coefficients by aerosol (a) and $\mathrm{BrC}$ (b) for two distinct periods. 
respectively, but they increased to 1.0-2.1 and 3.4-6.0 $\mu \mathrm{g} / \mathrm{m}^{3}$ during " $\mathrm{B}$ " period, respectively, with a rapid increase in $\mathrm{BC}_{370}$. This result suggests that the $\mathrm{PM}_{2.5}$ observed during "B" period was significantly influenced by light absorbing organic aerosols at the site, the presence of which was also demonstrated by enhanced aerosol and $\mathrm{BrC}$ absorption coefficients as shown in Fig. 7. The aerosol $\mathrm{AAE}_{370-950}$ and $\mathrm{BrC} \mathrm{b}_{\mathrm{abs}, 370}$ were 1.6 and $10.8 \mathrm{Mm}^{-1}$ during the "A" period, but increased to 2.1 and $62.6 \mathrm{Mm}^{-1}$ during the " $\mathrm{B}$ " period.

\subsection{Size Distribution of Water-soluble Chemical Species and Its Implication to BrC Absorption}

Fig. 8 shows the mass size distributions of $\mathrm{PM}, \mathrm{NO}_{3}^{-}, \mathrm{SO}_{4}{ }^{2-}$, WSOC, oxalate, $\mathrm{K}^{+}, \mathrm{Cl}^{-}$, and $\mathrm{Ca}^{2+}$ concentrations for typical, pollution event I, pollution event $\mathrm{II}$, and $\mathrm{AD}$ event. Moreover, average concentrations of WSOC, $\mathrm{NO}_{3}{ }^{-}, \mathrm{SO}_{4}{ }^{2-}$, oxalate, $\mathrm{NH}_{4}{ }^{+}$, and $\mathrm{K}^{+}$in $\mathrm{PM}_{1.8}$ (calculated from the sum of MOUDI impactor stages up to cut size of $1.8 \mu \mathrm{m}$ ) are summarized in Table 1 for the four different periods. As shown in Table 1, WSOC, $\mathrm{NO}_{3}^{-}$, and $\mathrm{NH}_{4}{ }^{+}$concentrations in $\mathrm{PM}_{1.8}$ were highest during pollution event $\mathrm{I}$, while $\mathrm{SO}_{4}{ }^{2-}$ and oxalate concentrations were highest during pollution event II. Higher $\mathrm{NO}_{3}^{-}$during pollution event I could be due to aqueous-phase oxidation processes of $\mathrm{NO}_{2}$ from local traffic activity (Fig. 1 and 2). However, higher $\mathrm{SO}_{4}{ }^{2-}$ during pollution event II suggests the influence of long-range transported aerosols from mid-eastern Chinese regions, as supported by transport pathways of air masses and MODIS images (see Fig. 3). For the four sampling periods, PM had a bi-modal size distribution peaking at 0.32 or $1.0 \mu \mathrm{m}$ (fine mode) and 3.1 or $6.2 \mu \mathrm{m}$ (coarse mode). Predominant mode of PM was observed in fine mode during the typical and two pollution events, and in coarse mode during $\mathrm{AD}$ event. In particular, $\mathrm{PM}$ during pollution event II showed a dominant droplet mode peaking at $1.0 \mu \mathrm{m}$, indicating an influence from more atmospheric processed or long-ranged transported aerosol components during this event.

For the pollution event $\mathrm{I}_{1} \mathrm{NO}_{3}^{-}, \mathrm{SO}_{4}{ }^{2-}$, WSOC, oxalate, and $\mathrm{K}^{+}$ concentrations exhibited a dominant condensation mode peaking at $0.32 \mu \mathrm{m}$, suggesting that $\mathrm{NO}_{3}^{-}, \mathrm{SO}_{4}{ }^{2-}$, WSOC, and oxalate could likely be formed through homogenous oxidation processes of $\mathrm{NO}_{2}$, $\mathrm{SO}_{2}$, and VOCs, followed by the condensation on pre-existing particles [53]. The condensation mode $\mathrm{NO}_{3}{ }^{-}$and $\mathrm{SO}_{4}{ }^{2-}$ concentrations accounted for 27.6 and $34.0 \%$ of their total concentration, respectively. Furthermore, coexistence of condensation mode WSOC and $\mathrm{K}^{+}$suggests the impact of BB emissions [54, 55]. The condensation mode WSOC and $\mathrm{K}^{+}$contributed 35.3 and $20.3 \%$ to the total WSOC and $\mathrm{K}^{+}$, respectively.

For the pollution event II, $\mathrm{NO}_{3}^{-}, \mathrm{SO}_{4}^{2-}$, and oxalate concentrations exhibited a dominant condensation mode peaking at $0.32 \mu \mathrm{m}$, in which they had similar formation pathways, e.g., homogenous gas-phase reactions [2], but the size distributions of WSOC and $\mathrm{K}^{+}$concentrations showed a similar shape with a broad peak between 0.32 and $1.0 \mu \mathrm{m}$, possibly due to homogeneous and heterogeneous reactions and $\mathrm{BB}$ emissions. Condensation mode $\mathrm{NO}_{3}^{-}, \mathrm{SO}_{4}^{2-}$, and oxalate concentrations contributed $21.3,26.2$, and $28.3 \%$, respectively, to their total concentrations, respectively. WSOC and $\mathrm{K}^{+}$concentrations contributed 25.5 and $15.2 \%$, respectively, to their total concentrations at $0.32 \mu \mathrm{m}$, as well as 26.8 and $18.2 \%$, respectively, at $0.55 \mu \mathrm{m}$, and 21.3 and $18.2 \%$, respectively, at $1.0 \mu \mathrm{m}$. WSOC and $\mathrm{K}^{+}$concentrations at particle size of 0.32-1.0 $\mu \mathrm{m}$ contributed to 73.6 and $51.6 \%$ to their total concentrations, respectively.

However, during the $\mathrm{AD}$ event, the $\mathrm{PM}, \mathrm{NO}_{3}{ }^{-}, \mathrm{SO}_{4}{ }^{2-}$, WSOC, and $\mathrm{K}^{+}$showed dominant condensation mode size distributions peaking at $0.32 \mu \mathrm{m}$ and a coarse mode peaking with a particle size of 3.1 or $6.1 \mu \mathrm{m}$. Their condensation mode size distributions were likely associated with homogenous reactions of precursor gases. In coarse mode, however, $\mathrm{NO}_{3}{ }^{-}, \mathrm{SO}_{4}{ }^{2-}$, and WSOC were probably associated with soil dust particles $\left(\mathrm{Ca}^{2+}\right)$ or sea salt $\left(\mathrm{Na}^{+}\right)$ particles, as discussed in previous studies [39, 41, 56]. As shown in Fig. 7, size distribution of $\mathrm{Cl}^{-}$had a predominant coarse mode peaking at $6.1 \mu \mathrm{m}$ for four sampling periods, but with a prominent mode during the $\mathrm{D}$ event. A very similar distribution was also observed for $\mathrm{Ca}^{2+}$. The size distribution of $\mathrm{Na}^{+}$is not shown here but it was very similar to that of $\mathrm{Cl}^{-}$for the four sampling periods, with $\mathrm{R}^{2}$ ranging from 0.70 (pollution episode II) to 0.88 ( $\mathrm{AD}$ event), indicating that they are from a similar source. Furthermore, the size distribution of $\mathrm{Ca}^{2+}$ was very strongly associated with that of $\mathrm{Cl}^{-}$, with $\mathrm{R}^{2}$ values of 0.84 ( $\mathrm{AD}$ event) - 0.90 (typical period). Generally, the coarse mode $\mathrm{Na}^{+}$and $\mathrm{Cl}^{-}$are mostly from marine aerosols, and $\mathrm{Ca}^{2+}$ is derived from soil $\mathrm{CaCO}_{3}$ particles. Once they are emitted in the atmosphere, thus, the reactions of $\mathrm{NaCl}$ and $\mathrm{CaCO}_{3}$ with $\mathrm{HNO}_{3}$ and $\mathrm{H}_{2} \mathrm{SO}_{4}$ during transport may produce the coarse mode $\mathrm{NO}_{3}{ }^{-}$and $\mathrm{SO}_{4}{ }^{2-}$ [40]. A study conducted by our group also indicated that the coarse mode WSOC was possibly condensed on the surfaces of the produced $\mathrm{Ca}\left(\mathrm{NO}_{3}\right)_{2}$ and $\mathrm{CaSO}_{4}$ particles [39, 56]. As a consequence, the results from previous studies and the coexistence of coarse mode WSOC, $\mathrm{Na}^{+}, \mathrm{Cl}^{-}$, and $\mathrm{Ca}^{2+}$ suggest that the coarse mode WSOC during $\mathrm{AD}$ event was possibly condensed on the surface of the $\mathrm{NaNO}_{3}$ and $\mathrm{Na}_{2} \mathrm{SO}_{4}$ and/or the $\mathrm{Ca}\left(\mathrm{NO}_{3}\right)_{2}$ and $\mathrm{CaSO}_{4}$ particles. Contributions of the coarse mode $\mathrm{NO}_{3}^{-}, \mathrm{SO}_{4}^{2-}$, WSOC, $\mathrm{K}^{+}, \mathrm{Cl}^{-}$, and $\mathrm{Ca}^{2+}$ during $\mathrm{AD}$ event were $34.5,10.5,22.7,24.2,53.6$, and $49.8 \%$ of their total concentrations at a particle size bin of 3.1-6.1 $\mu \mathrm{m}$, respectively.

As shown in Fig. 8, the size distributions of WSOC during the entire study period were similar to those of $\mathrm{NO}_{3}^{-}, \mathrm{SO}_{4}{ }^{2-}$, oxalate, or $\mathrm{K}^{+}$. To further examine size-resolved WSOC sources, the correlation analyses between WSOC and chemical species (oxalate, $\mathrm{NO}_{3}{ }^{-}$, $\mathrm{SO}_{4}{ }^{2-}$, and $\mathrm{K}^{+}$) at particle sizes of $0.32 \mu \mathrm{m}, 0.55 \mu \mathrm{m}, 1.0 \mu \mathrm{m}$, and $\mathrm{PM}_{1.8}$ were performed, and the results are summarized in Table 2. Fine mode WSOC $\left(\mathrm{PM}_{1.8}\right)$ was strongly correlated with oxalate $\left(\mathrm{R}^{2}=0.76\right)$ and moderately correlated with $\mathrm{NO}_{3}{ }^{-}\left(\mathrm{R}^{2}=\right.$ $0.55)$ and $\mathrm{SO}_{4}{ }^{2-}\left(\mathrm{R}^{2}=0.42\right)$. However, $\mathrm{R}^{2}$ values between WSOC and chemical markers depend on particle size and chemical markers, as shown in Table 2. As shown in Table 2, droplet mode WSOC (0.55-1.0 $\mu \mathrm{m}$ size bins) was strongly associated with $\mathrm{K}^{+}$ $\left(\mathrm{R}^{2}=0.70-0.82\right)$ and oxalate $\left(\mathrm{R}^{2}=0.68-0.64\right)$, suggesting that $\mathrm{BB}$ emissions and secondary organic aerosol formation could be possible sources of the droplet mode WSOC. Meanwhile the condensation mode WSOC had good-to-strong correlations with $\mathrm{NO}_{3}{ }^{-}$ $\left(\mathrm{R}^{2}=0.68\right)$ and oxalate $\left(\mathrm{R}^{2}=0.59\right)$, suggesting that secondary formation processes (e.g., homogenous gas-phase oxidations) similar to those of condensation mode $\mathrm{NO}_{3}^{-}$and oxalate were likely associated with condensation mode WSOC formation during the study period. 

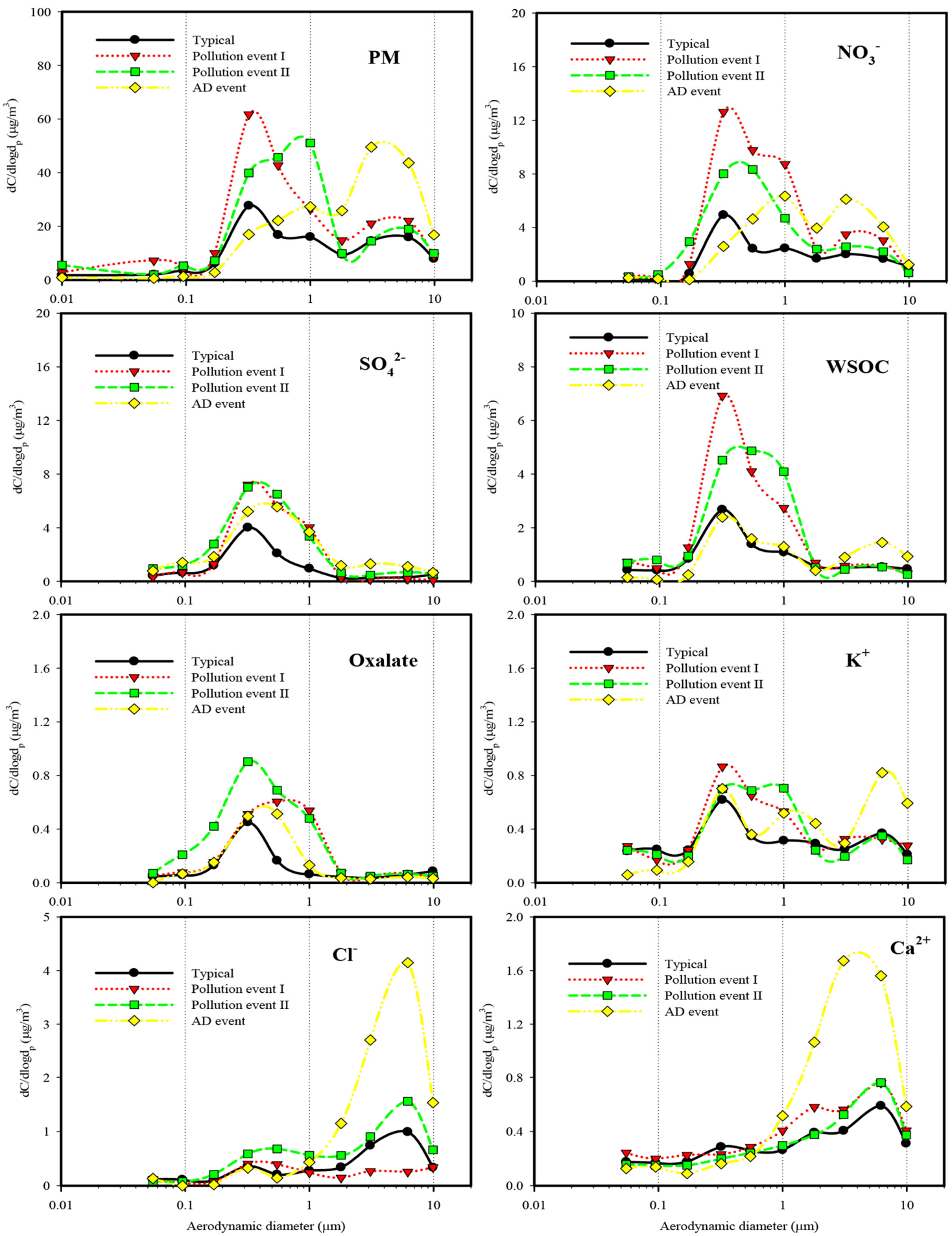

Fig. 8. Mass size distribution of $\mathrm{PM}, \mathrm{NO}_{3}{ }^{-}, \mathrm{SO}_{4}{ }^{2-}$, WSOC, oxalate, $\mathrm{K}^{+}, \mathrm{Cl}^{-}$, and $\mathrm{Ca}^{2+}$ for four different $\mathrm{PM}$ pollution cases.

It was confirmed in a previous section that the absorption due to aerosol particles was related to BrC. To further demonstrate the relationship between absorption by $\mathrm{BrC}$ at $370 \mathrm{~nm}$ estimated from the aethalometer $\left(\mathrm{BrC} \mathrm{b}_{\mathrm{abs}, 370}\right)$ and size-resolved water-soluble chemical markers (WSOC, oxalate, and $\mathrm{K}^{+}$), we carried out correlation analyses between estimated $\mathrm{BrC} \mathrm{b}_{\mathrm{abs}, 370}$ and size-resolved concentrations of three chemical markers for various particle sizes $\left(\mathrm{PM}_{1.8}, 1.00,0.55\right.$, and $\left.0.32 \mu \mathrm{m}\right)$. Their results are summarized 
Table 2. Coefficients of Determination $\left(\mathrm{R}^{2}\right)$ between Size-resolved WSOC, Oxalate, $\mathrm{K}^{+}, \mathrm{NO}_{3}{ }^{-}$, and $\mathrm{SO}_{4}{ }^{2-}$

\begin{tabular}{cccccc}
\hline & Size ( $\boldsymbol{\mu m})$ & Oxalate & $\mathrm{K}^{+}$ & $\mathrm{NO}_{3}{ }^{-}$ & $\mathrm{SO}_{4}{ }^{2-}$ \\
\hline \multirow{4}{*}{ WSOC } & $\mathrm{PM}_{1.8}$ & $0.76^{* *}$ & $0.38^{*}$ & $0.55^{* *}$ & $0.42^{* *}$ \\
& 1.00 & $0.64^{* *}$ & $0.82^{* *}$ & $0.27^{*}$ & $0.47^{* *}$ \\
& 0.55 & $0.68^{* *}$ & $0.70^{* *}$ & $0.47^{* *}$ & $0.50^{* *}$ \\
& 0.32 & $0.59^{* *}$ & $0.42^{* *}$ & $0.68^{* *}$ & $0.43^{* *}$ \\
\hline
\end{tabular}

Note) * and ** are significant at p values of $<0.05$ and $<0.01$, respectively.

Table 3. Coefficients of Determination $\left(\mathrm{R}^{2}\right)$ between $\mathrm{PM}_{2.5} \mathrm{BrC} \mathrm{b}_{\mathrm{abs}, 370}$ and Size-resolved WSOC, Oxalate, and $\mathrm{K}^{+}$

\begin{tabular}{rcccc}
\hline & Size $(\boldsymbol{\mu m})$ & WSOC & Oxalate & $\mathrm{K}^{+}$ \\
\hline & $\mathrm{PM}_{1.8}$ & $0.73^{* *}$ & $0.81^{* *}$ & $0.21^{*}$ \\
$\mathrm{PM}_{2.5} \mathrm{BrC} \mathrm{b}_{\mathrm{abs}, 370}$ & 1.00 & $0.67^{* *}$ & $0.51^{* *}$ & $0.57^{* *}$ \\
& 0.55 & $0.72^{* *}$ & $0.61^{* *}$ & $0.64^{* *}$ \\
& 0.32 & $0.56^{* *}$ & $0.74^{* *}$ & $0.16^{*}$ \\
\hline
\end{tabular}

Note) ${ }^{*}$ and ${ }^{* *}$ are significant at $\mathrm{p}$ values of $<0.05$ and $<0.01$, respectively.

in Table 3. Organic markers such as WSOC and oxalate were used to investigate the influence of secondary organic aerosols on light absorption by $\mathrm{BrC}$ aerosols [4], while the water-soluble $\mathrm{K}^{+}$was used to examine the influence from $\mathrm{BB}$ emissions on the BrC absorption [54, 55, 57]. As shown in Table 3, BrC babs,370 had moderate-to-strong correlations with size-resolved WSOC with $\mathrm{R}^{2}$ values ranging from 0.56 to 0.73 and size-resolved oxalate with $\mathrm{R}^{2}$ values of 0.51-0.81, respectively. This indicates that BrC absorption in the near UV range was related to formation of WSOC and oxalate existing in condensation and droplet particle, e.g., secondary organic aerosols. Furthermore, $\mathrm{BrC} \mathrm{b}_{\mathrm{abs}, 370}$ had good correlations with the droplet mode $\mathrm{K}^{+}$at particle sizes of 0.55 and $1.0 \mu \mathrm{m}$, but had low correlations with $\mathrm{K}^{+}$at sizes of 0.32 $\mu \mathrm{m}$ and $\mathrm{PM}_{1.8}$, suggesting that $\mathrm{BrC}$ absorption was likely associated with droplet mode $\mathrm{K}^{+}$at 0.55 or $1.0 \mu \mathrm{m}$ from $\mathrm{BB}$ emissions.

\section{Conclusions}

Daily averaged size-segregated filter samples were collected at an urban site from October 19 to November 09, 2017, to examine the impact of pollution and $\mathrm{AD}$ events on the water-soluble chemical composition and size distribution of aerosol particles in that area. Moreover, light absorption by aerosol and $\mathrm{BrC}$ particles was discussed between typical, two pollution events, and an $\mathrm{AD}$ event. Based on the 24-h Korean $\mathrm{PM}_{2.5}$ standard and the $\mathrm{AD}$ event, the entire study period was classified into four periods; typical, pollution event I, pollution event II, and AD.

Stable atmospheric conditions such as low wind speed and high surface pressure were observed during the two pollution events I and II, leading to enhanced concentrations of $\mathrm{PM}_{2.5}, \mathrm{BC}_{370}$, $\mathrm{BC}_{880}$, and $\mathrm{CO}$, and increased aerosol light absorption coefficients. Furthermore, low wind speeds and high RH conditions during the pollution events gave rise to the accumulation of aerosol particles and can promote the formation of secondary organic and inorganic aerosol species $\left(\mathrm{NO}_{3}{ }^{-}\right.$and $\left.\mathrm{SO}_{4}{ }^{2-}\right)$, resulting in dominant condensation and/or droplet mode size distributions for WSOC, $\mathrm{NO}_{3}{ }^{-}$, and $\mathrm{SO}_{4}{ }^{2-}$. Difference in the accumulation mode size distributions of water-soluble chemical species between pollution events I and II could be attributed to the difference in transport pathways of air masses from high-pollution regions and the formation processes for the secondary chemical species. In addition, the result from this study suggests that $\mathrm{BrC}$ absorption in the near UV range during fall at the site was influenced by both secondary organic aerosols and BB emissions. Overall, the pollution events observed during the fall season at an urban site of Gwangju, Korea can be due to the synergy of poor dispersion conditions, enhanced secondary formation, local emissions, and long-range transportation of air masses from upwind polluted areas.

\section{Acknowledgments}

This research was supported by the National Strategic Project-Fine Particle of the National Research Foundation of Korea (NRF) funded by the Ministry of Science and ICT (MSIT), the Ministry of Environment (ME), and the Ministry of Health and Welfare (MOHW) (2017M3D8A1092015). Also this study was supported by the Basic Science Research Programs through the NRF funded by the Ministry of Education (MOE) (NRF-2017R1D1A3A0 3000511).

\section{References}

1. Bae MS, Shin JS, Lee KY, Lee KH, Kim YJ. Long-range transport of biomass burning emissions based on organic molecular markers and carbonaceous thermal distribution. Sci. Total Environ. 2014;466:56-66

2. Yu G, Park S, Lee K. Source contributions and potential source regions of size-resolved water-soluble organic carbon measured at an urban site over one year. Environ. Sci. Proc. Imp. 2016;18:1343-1358.

3. Yu G, Zhang Y, Cho SY, Park S. Influence of haze pollution on water-soluble chemical species in $\mathrm{PM}_{2.5}$ and size-resolved particles at an urban site during fall. J. Environ. Sci. 2017;57:370-382.

4. Park S, Schauer J, Cho S. Sources and their contributions to two water-soluble organic carbons observed at a roadway site. Atmos. Environ. 2013;77:348-357.

5. Park S, Cho S, Bae M. Source identification of water-soluble organic aerosols at a roadway site using a positive matrix factorization analysis. Sci. Total Environ. 2015;533:410-421.

6. Zhao M, Xiu G, Qiao T, Li Y, Yu J. Characteristics of haze pollution episodes and analysis of a typical winter haze process in Shanghai. Aerosol Air Qual. Res. 2016;16:1625-1637.

7. Kim, KW, He Z, Kim YJ. Physicochemical characteristics and radiative properties of Asian dust particles observed at Kwangju, Korea, during the 2001 ACE-Asia intensive ob- 
servation period. J. Geophys. Res. 2004;109:D19S02.

8. Li H, Ma Y, Duan F, et al. Typical winter haze pollution in Zibo, an industrial city in China: Characteristics, secondary formation, and regional contribution. Environ. Pollut. 2017;229:339-349.

9. Ma Q, Wu Y, Zhang D, et al. Roles of regional transport and heterogeneous reactions in the $\mathrm{PM}_{2.5}$ increase during winter haze episodes in Beijing. Sci. Total Environ. 2017;599600:246-253.

10. Yu GH, Park SS, Park JS, et al. Pollution characteristics of $\mathrm{PM}_{2.5}$ observed during winter and summer in Baengryeongdo and Seoul. J. Korean Soc. Atmos. Environ. 2018;34:38-55.

11. Zhang QH, Zhang JP, Xue HW. The challenge of improving visibility in Beijing. Atmos. Chem. Phys. 2010;10:7821-7827.

12. Guo S, Hu M, Zamora M. Elucidating severe urban haze formation in China. Proc. Natl. Acad. Sci. 2014;111:17373-17378.

13. Huang RJ, Zhang YL, Bozzetti C. High secondary aerosol contribution to particulate pollution during haze events in China. Nature 2014;514:218-222.

14. Wang QQ, Sun YL, Jiang Q. Chemical composition of aerosol particles and light extinction apportionment before and during the heating season in Beijing, China. J. Geophys. Res. 2015;120:708-722.

15. Zhang Y, Huang W, Cai TQ. Concentrations and chemical compositions of fine particles $\left(\mathrm{PM}_{2.5}\right)$ during haze and non-haze days in Beijing. Atmos. Res. 2016;174-175:62-69.

16. Park S, Jung S, Gong B, Cho SY, Lee SJ. Characteristics of $\mathrm{PM}_{2.5}$ haze episodes revealed by highly time-resolved measurements at an air pollution monitoring supersite of Korea. Aerosol Air Qual. Res. 2013;13:957-976.

17. Yu GH, Park SS, Kim YS, et al. Difference in chemical composition of $\mathrm{PM}_{2.5}$ and investigation of its causing factors between 2013 and 2015 in air pollution intensive monitoring stations. J. Korean Soc. Atmos. Environ. 2018;34:16-37.

18. Chen L, Chow J, Doddridge B, et al. Analysis of a summertime $\mathrm{PM}_{2.5}$ and haze episode in the Mid-Atlantic region. J. Air Waste Manage. 2003;53:946-956.

19. Park SS, Harrison D, Pancras JP, Ondov JM. Highly time-resolved organic and elemental carbon measurements at the Baltimore Supersite in 2002. J. Geophys. Res. 2005;110:D07S06.

20. Park S, Kleissl J, Harrison D, et al. Characteristics of $\mathrm{PM}_{2.5}$ episodes revealed by semi-continuous measurements at the Baltimore Supersite at Ponca St. Aerosol Sci. Technol. 2006;40:845-860.

21. Park S, Kim J, Jeong J. Abundance and sources of hydrophilic and hydrophobic water-soluble organic carbon at an urban site in Korea in summer. J. Environ. Monit. 2012;14:224-232.

22. Zheng GJ, Duan FK, Su H, et al. Exploring the severe winter haze in Beijing: The impact of synoptic weather, regional transport and heterogeneous reactions. Atmos. Chem. Phys. 2015;15:2969-2983.

23. Jiang J, Zhou W, Cheng Z, Wang S, He K, Hao J. Particulate matter distributions in China during a winter period with frequent pollution episodes (January 2013). Aerosol Air Qual. Res. 2015;15:494-503.

24. Sun YL, Wang ZF, Fu PQ, et al. Aerosol composition, sources and processes during wintertime in Beijing, China. Atmos.
Chem. Phys. 2013;13:4577-4592.

25. Sun YL, Wang ZF, Du W, et al. Long-term real-time measurements of aerosol particle composition in Beijing, China: Seasonal variations, meteorological effects, and source analysis. Atmos. Chem. Phys. 2015;15:10149-10165.

26. Andreae MO, Ramanatham V. Climate's dark forcing. Science 2013;340:280-281.

27. Park SS, Son SC. Relationship between carbonaceous components and aerosol light absorption during winter at an urban site of Gwangju, Korea. Atmos. Res. 2017;185:73-83.

28. Park SS, Yu GH, Lee S. Optical absorption characteristics of brown carbon aerosols during the KORUS-AQ campaign at an urban site. Atmos. Res. 2018;203:16-27.

29. Kirchstetter TW, Novakov T, Hobbs PV. Evidence that spectral dependence of light absorption by aerosols is affected by organic carbon. J. Geophys. Res. 2004;109:D21208.

30. Laskin A, Laskin J, Nizkorodov SA. Chemistry of atmospheric brown carbon. Chem. Rev. 2015;115:4335-4382.

31. Andreae MO, Gelencsér A. Black carbon or brown carbon? The nature of light-absorbing carbonaceous aerosols. Atmos. Chem. Phys. 2006;6:3131-3148.

32. Cheng Y, He K, Du Z, et al. The characteristics of brown carbon aerosol during winter in Beijing. Atmos. Environ. 2016;127:355-364.

33. Hecobian A, Zhang X, Zheng M, Frank N, Edgerton ES, Weber RJ. Water-soluble organic aerosol material and the light-absorption characteristics of aqueous extracts measured over the Southeastern United States. Atmos. Chem. Phys. 2010;10: 5965-5977.

34. Hoffer A, Gelencsér A, Guyon P, et al. Optical properties of humic-like substances (HULIS) in biomass-burning aerosols. Atmos. Chem. Phys. 2006;6:3563-3570.

35 Park S, Yu J. Chemical and light absorption properties of humic-like substances from biomass burning emissions under controlled combustion experiments. Atmos. Environ. 2016;136: 114-122.

36. Wu GM, Cong ZY, Kang SC, et al. Brown carbon in the cryosphere: Current knowledge and perspective. Adv. Climate Change Res. 2016;7:82-89.

37. Ondov JM, Wexler AW. Where do particulate toxins reside? An improved paradigm for the structure and dynamics of the urban mid-Atlantic aerosol. Environ. Sci. Technol. 1998;32: 2547-2555.

38. Park S, Shin D. Characteristic of size-resolved water-soluble organic carbon in atmospheric aerosol particles observed during daytime and nighttime in an urban area. Part. Aerosol Res. 2013;9:7-21.

39. Park S, Son S. Size distribution and sources of humic-like substances in an urban ambient air during winter. Environ. Sci. Proc. Imp. 2016;18:32-41.

40. Huang XF, Yu JZ, He LY, Yuan Z. Water-soluble organic carbon and oxalate in aerosols at a coastal urban site in China: Size distribution characteristics, sources, and formation mechanisms. J. Geophys. Res. 2006;111:D22212.

41. Timonen H, Saarikoski S, Tolonen-Kivimäki O, et al. Size distributions, sources and source areas of water-soluble organic carbon in urban background air. Atmos. Chem. Phys. 2008;8:5635-5647. 
42. Xu JZ, Zhang Q, Wang ZB, et al. Chemical composition and size distribution of summertime $\mathrm{PM}_{2.5}$ at a high altitude remote location in the northeast of the Qinghai-Xizang (Tibet) Plateau: Insights into aerosol sources and processing in free troposphere. Atmos. Chem. Phys. 2015;15:5069-5081.

43. Drinovec L, Močnik G, Zotter P, et al. The "dual-spot" Aethalometer: An improved measurement of aerosol black carbon with real-time loading compensation. Atmos. Meas. Tech. 2015;8:1965-1979.

44. Martinsson J, Eriksson AC, Elbæk Nielsen I, et al. Impacts of combustion conditions and photochemical processing on the light absorption of biomass combustion aerosol. Environ. Sci. Technol. 2015;49:14663-14671.

45. Han T. Liu SC, Zhang YH. Role of secondary aerosols in haze formation in summer in the Megacity Beijing. J. Environ. Sci. 2015;31:51-60.

46. Quan JN, Liu Q, Li X, et al. Effect of heterogeneous aqueous reactions on the secondary formation of inorganic aerosols during haze events. Atmos. Environ. 2015;122:306-312.

47. Rolph G, Stein A, Stunder B. Real-time Environmental Applications and Display sYstem: READY. Environ. Modell. Softw. 2017;95:210-228.

48. Magee Scientific. The Aethalometer ${ }^{\mathrm{TM}}$. Berkeley, California: Magee Scientific Company; 2005.

49. Schnaiter M, Horvath H, Möhler O, Naumann KH, Saathoff H, Schöck OW. UV-VIS-NIR spectral optical properties of soot and soot-containing aerosols. J. Aerosol Sci. 2003;34:1421-1444.

50. Bergstrom R, Pilewskie P, Russell P, et al. Spectral absorption properties of atmospheric aerosols. Atmos. Chem. Phys. 2007;7:5937-5943.

51. Bergstrom RW, Pilewskie P, Pommier J, et al. Spectral absorption of solar radiation by aerosols during ACE-Asia. J. Geophys. Res. 2004;109:D19S15.

52. Sun H, Biedermann L, Bond TC. Color of brown carbon: A model for ultraviolet and visible light absorption by organic carbon aerosol. Geophys. Res. Lett. 2007;34:L17813.

53. Seinfeld JH, Pandis SN. Atmospheric chemistry and physics: From air pollution to climate change. 2nd ed. Hoboken, New Jersey: John Wiley \& Sons, Inc.; 2006.

54. Ichikawa Y, Naito S. Chemical compositions of primary $\mathrm{PM}_{2.5}$ derived from biomass burning emissions. Asian J. Atmos. Environ. 2017;11:79-95.

55. Yu J, Yu GH, Park S, Bae MS. Chemical and absorption characteristics of water-soluble organic carbon and humic-like substances in size-segregated particles from biomass burning emissions. Asian J. Atmos. Environ. 2017;11:96-106.

56. Park SS, Kim JH. Possible sources of two size-resolved water-soluble organic carbon fractions at a roadway site during fall season. Atmos. Environ. 2014;94:134-143.

57. Park SS, Sim SY, Bae MS, Schauer JJ. Size distribution of water-soluble components in particulate matter emitted from biomass burning. Atmos. Environ. 2013;73:62-72. 